\title{
МОТИВАЦІЙНО-ЦІННІСНА СКЛАДОВА ПІДГОТОВКИ МАЙБУТНЬОГО ВЧИТЕЛЯ ФІЗИЧНОЇ КУЛЬТУРИ ДО ЗДІЙСНЕННЯ ЗДОРОВ'ЯЗБЕРЕЖУВАЛЬНОЇ ДІЯЛЬНОСТІ
}

\author{
Танасійчук Юлія, \\ Уманський державний педагогічний університет імені Павла Тичини, Україна, \\ ORCID ID https://orcid.org/0000-0001-7772-1509
}

DOI: https://doi.org/10.31435/rsglobal_ws/30062020/7118

\section{ARTICLE INFO}

Received: 17 April 2020

Accepted: 10 June 2020

Published: 30 June 2020

\section{KEYWORDS}

motivational-and-valuable sphere, preparation,

future teacher,

physical education, health-care activity.

\begin{abstract}
The motivational-and-valuable component of future physical education teacher-preparation to implementation of health-care activity is analyzed in the article. It is established that it characterizes: maturity and hierarchy of motives in a healthy lifestyle based on value orientations, the attitude of future professionals to a healthy lifestyle and their future profession as the most valuable thing. Hence, the motivating factors are divided into three groups: needs, motives, values (attitudes). It is assumed that needs (as a source of motivation), motives (as causes of motivation) and attitudes (as a mechanism of motivation) are elements of the first level of the hierarchical structure of motivational readiness. It is proved that the other elements are derived from them. In particular the derivatives include will, emotions, values, needs.

Indicators of the motivational-and-valuable sphere are selected: motivational conviction and valuable attitude to professional activity (focus on forming a valuable attitude to the pupils' own health by means of physical education; belief in the necessity of forming a healthy way of life of pupils), awareness of the social importance of a healthy that is necessary for preserving and promoting the individual's health; valuable attitude to the health of their pupils and their own health, awareness of health as a value, ability to realize their health needs in a specific activity, formation of a positive attitude and value-and-notional attitudes, belief in the need of a healthy life for self-improvement, self-affirmation, for the realization of life and professional goals; emotional and value attitude to a healthy lifestyle; the effectiveness of volitional efforts to show creative health in practice, the formation of qualities that characterize the psycho-emotional stability of the individual: endurance, tact, kindness, accuracy and diligence in promoting health.
\end{abstract}

Citation: Iuliia Tanasiichuk. (2020) Motivational-and-Valuable Component of Future Physical Education Teacher-Preparation to Implementation of Health-Care Activity. World Science. 6(58), Vol.3. doi: 10.31435/rsglobal_ws/30062020/7118

Copyright: (C) 2020 Iuliia Tanasiichuk. This is an open-access article distributed under the terms of the Creative Commons Attribution License (CC BY). The use, distribution or reproduction in other forums is permitted, provided the original author(s) or licensor are credited and that the original publication in this journal is cited, in accordance with accepted academic practice. No use, distribution or reproduction is permitted which does not comply with these terms.

Вступ. Мотиваційно-ціннісна підготовка майбутнього вчителя фізичної культури до здійснення здоров'язбережувальної діяльності викликана необхідністю формування у нього потреби у вихованні, підтримці, збереженні здоров'я учнів, в орієнтації учнів на здоровий спосіб життя. Опредмечена потреба, як відомо, стає мотивом, що спонукає майбутнього вчителя фізичної культури до здійснення здоров'язбережувальної діяльності. У основі його діяльності з формування здоров'я учнів повинні знаходитися цінності здоров'я, здорового способу життя, які приймають форму мотиву до здійснення здоров'язбережувальної діяльності. Здоровий спосіб життя самого вчителя має сенс в 
орієнтації на здоровий спосіб життя учнів. Він виступає перед учнями як зразок, який ціннісно опосередковується ними.

Аналіз мотиваційно-ціннісної підготовки студентів до діяльності дозволив систематизувати склад і структуру складових елементів і взаємодії між ними. До таких елементів відносяться потреби (як джерело активності в діяльності і детермінатора прояви інших елементів), мотиви (як причина активності в діяльності, як результат потреб), ціннісні орієнтації (як механізм реалізації потреб, як трансформація системи соціальних цінностей).

Мета. Без достатнього рівня мотивації неможливе досягнення якого б то не було результату. Успіх будь-якої діяльності багато в чому залежить від бажання, прагнення, інтересу до роботи, потреби в цій діяльності, тобто від наявності позитивних мотивів.

Аналіз досліджень. Для об'єктивної оцінки різні автори по-різному визначають мотиваційно-ціннісну підготовку майбутніх фахівців до здоров'язбережувальної діяльності 3 використанням різних показників, залежно від певного напряму їх дослідження (Т. Белінська [1], Д. Бермудес [2], О. Гришина [4], П. Гусак, Н. Зимівець [5], С. Давидова [6], Л. Слисеєва [7], Г. Іванова [8], Л. Іванова [9], С. Карасєвич [10], І. Кесицька [11], Н. Козак [12], М. Козуб [13], С. Крошка [14], В. Лобачев [15], Л. Малорошвило [16], Г. Миргородська [18], Л. Никифорова [19], О. Пашин [20], Н. Попова [21], Н. Свірщук [22], Н. Степанченко [24], О. Філіпп'єва [26]).

Результати дослідження. М. Козуб розводить поняття «мотивація» і «мотив», розуміючи мотив як бажаний цільовий стан в рамках відносин «індивід-середовище», а мотивацію як те, що пояснює цілеспрямованість дії [13, с.61].

Мотивація починає процес вибору з минулого досвіду всього того, що в житті індивіда пов'язане із задоволенням відчуття потреби і прийняття рішення опосередковано зі складним процесом зіставлення життєвого досвіду до умов конкретної ситуації. Процес закінчується висуненням мети дії як усвідомленого образу передбачення результату [20, с.50].

Мотивація зміцнює і організовує діяльність, інтегрує зовнішні і внутрішні спонукання в цілісне мотиваційне спонукання, що детермінує поведінку, діяльність в певній ситуації [7, с.103].

Мотивація здорового стилю життя, включена в структуру особистості, виконує певні функції, які проявляються у валеологічній спрямованості життедіяльності, організації навчальної діяльності, у їі формуванні.

У дослідженні I. Воробйової мотивація визначається як усвідомлення системних спонукань, що представляють собою ієрархічну структуру рушійних сил поведінки і діяльності особистості, що є інтеграцією особистості в ціле [3, с.79].

Існують різні фактори мотивації, які визначають, що є найбільш цінним, важливим для людини. Як правило, це не один фактор, а декілька i разом вони складають структуру мотиваційної сфери особистості.

За джерелом виникнення мотивації виділяються зовнішні та внутрішні фактори, що визначають характер мотивації студентів до формування в учнів ціннісного ставлення до власного здоров'я.

Зовнішні чинники мотивації: матеріальний добробут, кар'єра, статус, естетика побуту тощо. Вони націлені на отримання відсутнього об'єкта або, навпаки, уникання цього, тобто мотиви розрізняються ще і за характером: вони можуть бути позитивними (придбати, зберегти) або негативними (позбутися, уникнути) [3, с.57].

Внутрішня мотивація проявляється тільки тоді, коли поставлені цілі і зовнішні мотиви співвідносяться з можливостями і здібностями студентів, і коли вони розуміють суб'єктивну відповідальність за їх реалізацію. Успішна реалізація цілей і мотивів викликає у студентів натхнення успіхом, бажання продовжувати заняття за власною ініціативою, тобто активізуються внутрішня мотивація й інтерес.

Кожен аспект мотивації (специфічний і неспецифічний) здійснює вплив на процесуальні і результативні характеристики професійної діяльності [25, с.207].

Наступним елементом мотиваційної сфери є мотиви. Мотив можна визначити як таке ставлення особистості до діяльності, в основі якого лежить свідомо поставлена і певним чином обгрунтована мета. Мотиви $є$ не тільки збудником діяльності, а й стають характерними властивостями для самої особистості [7, с.64].

Вони, будучи причиною активності в діяльності, визначаються як відображення усвідомленої потреби (або ії об'єктів). Якщо потреба формує питання «чому я хочу це зробити?», то 
мотив - «що я хочу зробити?». Для людини властива наявність деякого числа мотивів. Між ними завжди виявляються відносини (ставлення), які мають динамічний характер. Виявляються провідні мотиви, які визначають спрямованість активності в діяльності. Надмірний розвиток будь-якого мотиву, при недостатньому розвитку інших, негативно позначається на розвитку особистості. Необхідною умовою тому є гармонійний розвиток системи мотивів. Система мотивів, що виникає на основі потреб, визначає спрямованість особистості, стимулює і мобілізує іiі на прояв активності.

Потреби і мотиви складають ієрархію, яка характеризує цілісну особистість у всіх сферах ¥ї діяльності, спонукає людину ставити проблеми, концентрувати зусилля на їх вирішенні [7, с.103].

Критеріями відбору для класифікації мотивів виступають: значимість для особистості, джерело виникнення мотивів (внутрішній, зовнішній), тривалість їх дії. На основі обраних критеріїв виділяються такі групи мотивів:

- широкий соціальний мотив (спрямованість на соціум) - усвідомлення суспільної значущості здоров'я;

- мотиви самовдосконалення (на себе): а) прагнення до гармонійного розвитку; б) прагнення до самовиховання (подолання шкідливих звичок, неорганізованості, регулювання режиму дня, дотримання правил особистої гігієни, зміна рис характеру);

- мотивації досягнень (на себе): а) потреба в необхідному рівні здоров'я; б) потреба в самовдосконаленні та самоствердженні (бути не гірше за інших, привабливим для протилежної статі, поліпшити статуру) за допомогою здорового способу життя;

- мотиви спілкування (на соціум): а) прагнення до створення позитивного психоемоційного фону в суспільстві; б) прагнення до плідної співпраці;

- професійні мотиви (на професію): а) усвідомлення значимості здорового стилю життя для професійної підготовки, професійної діяльності; б) потреба в оволодінні валеологічними знаннями, вміннями 3 організації навчальної і надалі професійної діяльності з валеологічних позицій; в) усвідомлення значущості професії педагога як особистого прикладу у вихованні здорового підростаючого покоління;

- мотиви прагнень: а) прагнення зміцнити або підтримати власне здоров'я після перенесеної хвороби; б) прагнення до наслідування (знайомих, друзів, батьків) у веденні здорового способу життя [9, с.61].

Наведений склад мотивів охоплює основні напрями мотиваційної сфери особистості студента, що враховує його вікові особливості та професійну спрямованість навчання.

I. Воробйова виділяє такі мотиви: мотив фізичного вдосконалення, пов'язаний 3 прагненням прискорити темпи власного, розвитку, зайняти гідне місце в своєму оточенні, домогтися визнання, поваги; мотив необхідності, пов'язаний з необхідністю відвідувати заняття 3 фізичної культури, виконувати вимоги навчальної програми; мотив суперництва, що характеризує прагнення виділитися, самоствердитися в своєму середовищі, домогтися авторитету, підняти свій престиж, бути першим, досягти якомога більшого; мотив наслідування, пов'язаний з прагненням бути схожим на тих, хто досяг великих успіхів у спортивній кар'єрі або має особливі якості і досягнення, набуті в результаті занять; спортивні мотиви, що визначають прагнення домогтися значних результатів; процесуальний мотив, при якому увага зосереджена не на результаті діяльності, а на самому процесі занять; мотиви комфортності, що визначають бажання займатися фізичними вправами в сприятливих умовах тощо [3, с.85].

Такі мотиви відмінні від мотивів просто пізнавальної діяльності. Це мотиви, які спонукають студентів до збереження та підтримання власного здоров'я, до орієнтації учнів на здоровий спосіб життя. Цінності здоров'я і здоровий спосіб життя, що привласнюються студентами, набувають форми мотиву оволодіння знанням про здоров'язбережувальні освітні технології, про способи їх реалізації, оволодіння досвідом створення та реалізації здоров'язбережувальних освітніх технологій [4, с.174].

Мотиваційна сфера має пряме відношення до вольової діяльності, оскільки в ній закладені спонукальні сили, які спрямовують людину до здійснення вольових дій, визначають характер і психологічні умови здійснення вольового акту [9, с.58].

Вольові якості характеризують потенційний аспект вольових зусиль, стають гарантією готовності до сталого та ефективного їх прояву. Одні вольові якості необхідні, щоб приступити до будь-якої діяльності, а інші - щоб іiі ефективно здійснити [9, с.70]. 
Таким чином, вольові якості, будучи індивідуальними рисами особистості людини, визначають успішність складної діяльності, тобто ііі доцільність, безперервність, надійність, ефективність.

Особливість мотиваційно-ціннісного ставлення до здорового способу життя у студентів необхідно розглядати у взаємодії з середовищем, в якому воно формується.

Складником мотиваційно-ціннісної сфери є потреби у вихованні, підтримці, збереженні здоров'я учнів, в орієнтації учнів на здоровий спосіб життя.

Слід погодитися з В. Філанковським, що необхідне виділення вихідних (первинних) потреб, для того, щоб відсікти безліч похідних. Під вихідними (первинними) потребами автор розуміє ті, які не виводяться одна з одної і не замінюють одна одну [25, с.207].

Проміжною ланкою процесу переходу потреби в мотив діяльності виступає інтерес до предмету цієї потреби. Стимулююча роль інтересу полягає в тому, що заснована на ньому діяльність i результати викликають у суб'єкта почуття радості, емоційного піднесення і задоволення, що і спонукає його до прояву активності. Застосування на уроках фізичної культури засобів оздоровлення викликає інтерес учнів при виконанні фізичних вправ.

Виходячи з вищевикладеного, відзначаємо, що значимість ставлення до власного здоров'я як професійної цінності полягає в наступному:

- усвідомленні індивідуальної значущості здорового способу життя;

- розумінні необхідності здорового способу життя для реалізації життєвих i професійних цілей;

- усвідомленні необхідності знання і застосування на практиці законів збереження i відновлення здоров'я і всіх систем життєзабезпечення;

- самостійному знаходженні власних шляхів розв'язання найбільш раціонального ставлення до формування здорового способу життя; $[23$, c.41].

- усвідомленні відповідальності за стан здоров'я як особистісної та професійної цінності

Ціннісні орієнтації та відносини являють собою найбільш гнучку форму регуляції поведінки і діяльності особистості, яка передбачає вільний вибір суспільних цінностей, на які вона орієнтується і якими керується в своїй діяльності [27, с.67].

Мотиваційно-ціннісний складник готовності включає такі професійні цінності: педагогічне спілкування, психолого-педагогічні знання, самовираження в професійнопедагогічній діяльності тощо, які виступають в якості відносно-стійких орієнтирів, за якими педагоги співвідносять своє життя і професійну діяльність. Вони необхідні як задоволення їх потреб, інтересів, ідей і мотивів, як норм, мети або ідеалу. Ці цінності становлять єдине ціле і тісно пов'язані з фізичною культурою, оскільки переплітаються з її сферами діяльності, зокрема фізкультурно-оздоровчою. Цінності фізичної культури мають раціональні форми рухової діяльності, які дозволяють формувати найкращим чином потрібні в житті рухові вміння i навички, забезпечують спрямований розвиток життєво важливих фізичних здібностей, оптимізують стан здоров'я і працездатність [7, с.64].

Пошук, усвідомлення і прийняття студентом особистісного сенсу цінності «здоров'я» передбачає здійснення ним спеціальної активності одночасно пізнавального і особистісного характеру, представленої у вигляді особистісних переваг.

Виділимо ієрархію ціннісних орієнтацій, які умовно об'єднані в три групи: духовноестетична визначає особистісну гармонію, життєву мудрість, творчість, свободу, самовдосконалення, рівність, терпимість, любов, красу природи і мистецтва; професійноорієнтована характеризує пізнання, цікаву роботу, раціональність, сумлінність, відповідальність, працездатність, суспільне визнання, впевненість в собі, матеріальну забезпеченість; практично-діяльнісна орієнтує на комфортність, здоров'я, спорт, задоволення, життерадісність, спілкування.

Ціннісний потенціал фізичної культури Л. Швед [27] пропонує умовно розділити на складові: інтелектуальні, рухові, технологічні та мобілізаційні цінності. Зміст інтелектуальних цінностей включає знання про методи і засоби розвитку фізичного потенціалу людини як основи організації його фізичної активності, загартовування і здорового способу життя. До цінностей рухового характеру автор відносить кращі зразки моторної діяльності, що досягаються у процесі фізичного виховання і спортивної підготовки, особисті досягнення в руховій підготовленості 
людини, iї реальний фізичний потенціал. Під технологічними цінностями розуміються різні комплекси методичних посібників, практичних рекомендацій, методики оздоровчої та спортивної тренування - все те, що напрацьовано фахівцями для забезпечення процесу фізичної і спортивної підготовки. Цінності інтенціонального характеру відображають сформованість громадської думки, престижність фізичної культури в даному суспільстві, іï популярність у різних категорій людей, а головне, їх бажання і готовність до постійного розвитку і вдосконалення потенціалу своєї фізичної культури. До цієї ж групи цінностей відносяться і соціально-психологічні установки, які визначаються характером, структурою та спрямованістю потреб, мотивацією ціннісних орієнтацій на заняття фізичними вправами і спортом.

Особливе значення Л. Швед [27] надає мобілізаційним цінностям фізичної культури. До них відносить: здатність до раціональної організації свого бюджету часу, внутрішню дисципліну, зібраність, швидкість оцінки ситуації та прийняття рішення, наполегливість в досягненні поставленої мети, уміння спокійно пережити невдачу і навіть поразку i, нарешті, просто «викрутитися» зі складної ситуації (хвороби, травми, аварійні ситуації, стихійні лиха, соціально обумовлені несподівані або довгострокові навантаження на психіку, фізичні перевантаження тощо).

Мобілізаційні цінності фізичної культури мають чітку валеологічну спрямованість: самоорганізація здорового способу життя, вміння протистояти несприятливим впливам зовнішнього середовища - результат освоєння валеологічних цінностей фізичної культури.

У роботі зі студентами С. Маркін [17] пропонує акцентувати увагу на їх професійноціннісних орієнтаціях, у які включені цінності фізичної культури: цінності, що створюють передумови вільного самовизначення і самоствердження у професійній діяльності, відображені в ii результатах і наслідках для суспільства і людей; цінності, що визначають найбільш повну самореалізацію особистості в праці відповідно до її здібностей і можливостей, які проявляються в задоволеності працею, умовами для самовдосконалення; цінності, що характеризують творчі можливості організації оптимального режиму і умов індивідуальної і колективної праці людей, що забезпечують високу продуктивність, самовіддачу, сприятливий соціально-психологічний клімат; цінності, що розкривають значущість використання відновлювальних заходів у вільний час, ведення здорового способу життя в цілому, під впливом яких підвищуються професійна надійність і дієздатність фахівця, формуються його соціальність і оптимізм [17, с.73].

Мотиваційно-ціннісна сфера характеризується усвідомленням здоров'я в якості однієї 3 основних життєвих цінностей і сформованою системою позитивного ставлення до здорового способу життя. Ціннісні відносини особистості в сфері ЗСЖ виникають в процесі дій спрямованих на задоволення тих чи інших потреб здоров'язбереження і проявляються в усвідомленні значущості або особистісного сенсу цієї діяльності або об'єкта діяльності в результаті емоційного переживання. Особистісні смисли здоров'язбереження $\epsilon$ важливим елементом підсистеми відносин або мотиваційно-ціннісного критерію, орієнтованого на всебічний гармонійний саморозвиток, а не лише на відсутність хвороб. Мотиваційно-ціннісний критерій передбачає розвиток особистісної сфери людини, забезпечує усвідомлення потреб і мотивів здоров'язбереження. Оскільки формування уявлень про закономірності ЗСЖ носить характер емоційно-осмисленого ставлення, то, ймовірно, потреби в позитивних емоціях, отриманих в процесі оздоровчих дій або занять фізкультурою і спортом, можуть служити підставою мотивів здоров'язбереження [20, с.46].

Аналіз складових мотиваційно-ціннісної сфери та їх змістова характеристика дали можливість виокремити її показники, до яких віднесено: мотиваційну переконаність та ціннісне ставлення до професійної діяльності (націленість на формування ціннісного ставлення до власного здоров'я учнів засобами фізичної культури; переконання в необхідності формування здорового способу життя учнів), усвідомлення соціальної значущості здоров'я та способу життя, необхідного для формування, збереження і зміцнення здоров'я особистості; ціннісне ставлення до здоров'я своїх вихованців і власного здоров'я, усвідомлення здоров'я як цінності, можливості реалізувати свої потреби в здоров"ї в конкретній діяльності, формування позитивного ставлення і ціннісно-смислових установок, переконання в необхідності здорової життєдіяльності для самовдосконалення, самоствердження, для реалізації життєвих i професійних цілей; емоційно-ціннісне ставлення до здорового способу життя; дієвість вольових зусиль для прояву здоров'ятворчості в практичній діяльності, формування якостей, що 
характеризують психоемоційну стійкість особистості: витримки, тактовності, доброзичливості, акуратності і старанності у зміцненні здоров'я.

Висновки. Аналіз мотиваційно-ціннісної підготовки майбутнього вчителя фізичної культури фізичної культури до здійснення здоров'язбережувальної діяльності показав, що іiі характеризує: зрілість і ієрархія мотивів в здоровому способі життя на основі ціннісних орієнтацій, ставлення майбутніх фахівців до здорового способу життя і своєї майбутньої професії як цінності. Звідси мотивуючі діяльність фактори розділені на три групи: потреби, мотиви, ціннісні орієнтації (установки). Можна вважати, що потреби (як джерело мотивації), мотиви (як причини мотивації) і установки (як механізм мотиваціі), є елементами першого рівня ієрархічної структури мотиваційної готовності. Всі інші елементи є похідними від них. Зокрема, до похідних віднесено волю, емоції, цінності, потреби.

\section{ЛIТЕРАТУРА}

1. Белинская Т. В. Психологические составляющие развития ценностного отношения к здоровью у студентов педагогического вуза: дис. ... канд. психол. наук: 19.00.07. Калуга, 2005. 174 с.

2. Бермудес Д. Обгрунтування моделі підготовки майбутніх учителів фізичної культури до реалізації варіативних модулів у процесі професійної діяльності. Педагогічні науки: теорія, історія, інновачійні технологіï. 2017. № 7. С. 26-36.

3. Воробьева И. Н. Формирование мотивационно-ценностного отношения подростков к здоровому образу жизни средствами физической культуры: дис. ... канд. пед. наук: 13.00.01. Владикавказ, 2014. 207 с.

4. Гришина Е. П. Формирование готовности будущего учителя физической культуры к созданию и реализации здоровьесберегающих образовательных технологий: дис. ... канд. пед. наук: 13.00.08. Самара, 2005.231 c.

5. Гусак П. М., Зимівець Н. В., Петрович В. С. Відповідальне ставлення до здоров'я: теорія та технології: монографія / за ред. П. М. Гусака. Луцьк: ВАТ «Волинська обласна друкарня», 2009. 219 с.

6. Давыдова С. А. Профессиональная подготовка будущих учителей физической культуры к формированию здоровьесберегающей стратегии обучающихся: дис. ... канд. пед. наук: 13.00.08. Махачкала, 2017. $211 \mathrm{c.}$

7. Елисеева Л. А. Подготовка учителя физической культуры к использованию нетрадиционных средств оздоровления учащихся на уроках и во внеурочное время: дис. ... канд. пед. наук: 13.00.08. Барнаул, 2005. 209 с.

8. Іванова Г. І. Характеристика поняття та компонентів культури здоров'я майбутніх вчителів. Фізична реабілітаиія та здоров'язбережувальні технології : реалії і перспективи : матеріали III Всеукр. наук.-практ. інтернет-конф. (Полтава, 9 лист. 2017 р.). Полтава : ПолтНТУ ім. Юрія Кондратюка, 2017. C. $111-113$.

9. Іванова Л. І. Професійна підготовка майбутніх учителів фізичної культури до роботи з учнями 3 відхиленнями у стані здоров'я: теорія та методика: монографія. Київ: НПУ імені М. П. Драгоманова, 2013. $600 \mathrm{c}$.

10. Карасєвич С. А. Підготовка майбутніх учителів фізичної культури до фізкультурно-спортивної діяльності у закладах загальної середньої освіти: монографія. Умань: ВПЦ «Візаві», 2018. 204 с.

11. Кенсицька I. Модель формування цінностей здорового способу життя студентів у процесі фізичного виховання. Теорія і методика фізичного виховання і спорту. 2017. № 4. С. 69-76.

12. Козак Н. Г. Здоров'язберігаюче виховання підлітків основної школи в навчально-виховному процесі: дис. ... канд. пед. наук: 13.00.07. Полтава, 2016. 240 с.

13. Козуб М. В. Формирование профессиональной готовности будущих учителей физической культуры к осуществлению здоровьесберегающей деятельности в школе: дис. ... канд. пед. наук: 13.00.08. Елец, 2007. $223 \mathrm{c.}$

14. Крошка С. А., Борисенко Л. Л., Єршов С. І. Підготовка майбутніх учителів початкових класів до впровадження здоров'язбережувальних технологій на уроках. Гуманізація навчально-виховного прочесу. 2014. Вип. LXIX. C. 205-212.

15. Лобачев В.В. Формирование здоровьесберсгающей компетенции в профессиональной подготовке будущего педагога физической культуры: дис. ... канд. пед. наук: 13.00.01; 13.00.08. Воронеж, 2006. 210 с.

16. Малорошвило Л. Н. Формирование готовности студентов вузов физкультурно-спортивного профиля к здоровьесбережению учащихся: дис. ... канд. пед. наук: 13.00.04. Челябинск, 2004. 171 с.

17. Маркин С. Н. Подготовка будущего учителя к самоорганизации здорового образа жизни средствами физической культуры: дис. ... канд. пед. наук: 13.00.08. Барнаул, 2004. 170 с.

18. Миргородська Г. М. Формування культури здоров'я у майбутніх кваліфікованих робітників будівельного профілю в процесі професійної підготовки: дис. ... канд. пед. наук : 13.00.04. Київ, 2017. $250 \mathrm{c}$. 
19. Никифорова Л. А. Формування професійної культури майбутніх учителів фізичного виховання в процесі фахової підготовки : автореф. дис. ... канд. пед. наук : 13.00.04. Одеса, 2017. 26 с.

20. Пашин А. А. Формирование ценностного отношения к здоровью в физическом воспитании учащейся молодежи: дис. ... д-ра пед. наук: 13.00.04. Москва, 2011. 413 с.

21. Попова Н. Г. Формирование ценностного отношения учащихся к здоровому образу жизни в образовательном процессе современной школы: дис. ... канд. пед. наук: 13.00.01. Великий Новгород, 2015. $253 \mathrm{c}$.

22. Свірщук Н. С. Підготовка майбутніх учителів фізичної культури до фізкультурно-рекреаційної роботи в школі : автореф. дис. ... канд. пед. наук : 13.00.04. Вінниця, 2013. 23 с.

23. Сорокина В. М. Формирование у студентов отношения к здоровому образу жизни как профессиональной ценности: дис. ... канд. пед. наук: 13.00.08. Волгоград, 2010. 241 с.

24. Степанченко Н. І. Система професійної підготовки майбутніх учителів фізичного виховання у вищих навчальних закладах : дис. ... д-ра пед. наук : 13.00.04. Вінниця, 2017. 629 с.

25. Филанковский В. В. Теория и практика формирования профессиональной готовности учителя физической культуры: дис. ... д-ра пед. наук: 13.00.01; 13.00.04. Ставрополь, 2000. 459 с.

26. Філіпп’єва О.А. Підготовка майбутніх учителів початкових класів до валеологічного виховання учнів : автореф. дис. ... канд. пед. наук : 13.00.04. Кіровоград, 2008. 23 с.

27. Швед Л. В. Подготовка студентов педвуза к формированию здорового образа жизни у школьников: дис. ... канд. пед. наук: 13.00.08. Чебоксары, 2007. 196 с. 